\title{
Sustaining Strong Institutions Through Compliance with the Rule of Law and Good Governance in Nigeria
}

\author{
Omoniyi Bukola Akinola, Ph.D \\ LL.B (Unilorin), LL.M (ABSU), PhD (UNIZIK), Barrister at Law and Senior Lecturer, Department of Corporate \\ Law Practice, Nigerian Law School, Kano Campus, Kano State, Nigeria
}

\begin{abstract}
Africa has struggles with leadership problems over the decades. More especially, Nigeria has struggled with bad leadership of the country through corrupt practices which culminates in paucity of social and human capital. There are cases of arbitrary military decrees in the past. The cumulative effective of previous autocratic regimes is that it enthrones the rule by individuals and dethrones institutional governance structure. The methodology adopted in this paper is based on literature review, governance experiences in the course of implementing government policies, and societal reactions and feedbacks from citizens. This paper examined the concept of rule of law vis-à-vis good governance as it ought to be for promotion of institutions above individuals in Nigeria. The paper anatomised challenges and effects of building and sustaining strong institutions in Nigeria.
\end{abstract}

Keywords: Rule of Law, Institutions, Good Governance

DOI: $10.7176 / \mathrm{JLPG} / 97-09$

Publication date:May $31^{\text {st }} 2020$

\section{Introduction}

It is a basic truism that adherence to rule of law gives birth to good governance. The pertinent question to ask is: what is Rule of Law? The answer is not far - fetched. It is basically, let the law have its rule. Rule of law entails clear institutional standards and enforcement. ${ }^{1}$ It is the exercise of state power using, and guided by, published written standards that embody widely-supported social values, avoid particularism, and enjoy broad-based public support. ${ }^{2}$ Simply put, Rule of Law connotes respect for general order of law. It is an ideology that appeals for unalloyed obedience to law and strict adherence to its stipulations. The historical advancement of the concept is widely attached to the theories of early philosophers. ${ }^{3}$ In the broadest terms, the rule of law requires that the state only subject the citizenry to publicly promulgated laws that the state's legislative functions are separate from the adjudicative function, and that no one within the polity should be above the law. ${ }^{4}$ The former Secretary General of the United Nations in 2013 defines the rule of law as a principle of governance in which all persons, institutions and entities are accountable to laws that are publicly promulgated, equally enforced and independently adjudicated, and which are consistent with international human rights, norms and standards. ${ }^{5}$ It requires, as well, measures to ensure adherence to the principles of supremacy of law, equality before the law, accountability to the law, fairness in the application of the law, separation of powers, participation in the decision making, legal certainty, avoidance of arbitrariness and procedural and legal transparency. Section 1 of the constitution of the Federal Republic of Nigeria provides for the rule by the constitution by conferring supremacy on the constitution. ${ }^{6}$

Governance simply means the process of decision making and the process by which decisions are implemented. ${ }^{7}$ good governance involves: enthronement of a democratic government, which guarantees equal participation of all citizens in governance; provision, promotion and sustenance of the rule of law; provision and protection of the constitution; promotion and protection of the fundamental human rights of the citizens; provision and sustenance of the freedom of the press; availability of a transparent, accountable and participatory governance at all levels of government; regular, free and fair elections; as well as provision of basic amenities, such as, portable water, electricity, qualitative education, healthcare delivery, good roads, among others. Governance has also been defined as the management of society by the people. ${ }^{8}$ It is simply the triumvirate of democracy, the rule of law and

\footnotetext{
${ }^{1}$ Michael Johnston, Good Governance: Rule of Law, Transparency, and Accountability. Being a Paper presented at the Department of Political Science, Colgate University. Page 2

${ }^{2}$ Ibid.

${ }^{3}$ P. A. Oluyede and D.O. Aibe, Cases and Mute mils on constitutional Law in Nigeria (University Press Plc, Ibadan: 2003 ) p57

${ }^{4}$ Michel Rosenfield. The Rule of Law and Constitutional Democracy. www.bcf.usc.edu/ usclrev/pdf/074503.pdf Accessed 1 August, 2019

${ }^{5}$ United Nations [2012] 'Report of the Secretary-General on the Rule of Law and Transitional Justice in Conflict and Post-Conflict Societies,' [S/2004/616].

${ }^{6}$ Section 1 (1): This Constitution is supreme and its provisions shall have binding force on the authorities and persons throughout the Federal Republic of Nigeria.

(2) The Federal Republic of Nigeria shall not be governed, nor shall any persons or group of persons take control of the Government of Nigeria or any part thereof, except in accordance with the provisions of this Constitution.

${ }^{7}$ Justice Y.K. Sabharwal, Chief Justice of India. The Role of the Judiciary in Good Governance.

${ }^{8}$ Albrow. M., Good Governance Practice for Better Performance of Community Organization. Journal of Power, Politics and Governance (2001) Vol 1 No. 12
} 
good governance ${ }^{1}$ This paper examines the effects of the triumvirate of democracy, the rule of law and good governance in Nigeria as a developing country vis-à-vis the practice of other democracies in terms of sustaining strong institutions at the expense of strong individuals. ${ }^{2}$ The paper shall further consider the level of adherence to section 1 of the constitutions vis-à-vis its supremacy over all persons and authorities in Nigeria.

\section{The Concept of Rule of Law}

Over the years, the rule of law has progressively developed and has metamorphosed to have so many faces and has produced different results. These results are negative and positive in most cases. In few others the result is one that shows a complete misunderstanding and misapplication of the concept for ends other than what it was intended to achieve. ${ }^{3}$ According to Esiemokhai, Governments must acknowledge that the rule of law is effective regulatory machinery that brings order and good governance to any society. The late Chief Justice Sir Adetokunbo Ademola told the African Conference on the Rule of Law, in Lagos in 1961, that "the rule of law is not a Western idea, nor is it linked up with any economic or social system. As soon as you accept that man is governed by law and not by whims of man; it is the rule of law. It is based on principles; it is not an abstract notion. ${ }^{4}$

The rule of law is not peculiar to democratic governance. For instance, in a monarchy, an individual is vested with powers for governing the citizen in line with his dictates, wishes, norms and customs of his people. Monarchy is not entirely about an individual, it also promotes separation of powers with checks and balances in some instances. Rule of law abhors rule of force. Globally, rule of law built on democratic tenets is the norm for good governance to thrive.

The various Nigerian Kingdoms under the Monarchy system of government adhered strictly to the dictates of traditional values and public order. Even Kings and Chiefs were sanctioned where they overreached societal norms and ancestral civility. Aristotle ${ }^{5}$ said that" the rule of law is preferable to the rule of man". The American Declaration of Independence (1776) and all the other human rights proclamations through the hurrying centuries, have upheld the rule of law. ${ }^{6}$

In a political system which adheres to the paramount principles of the rule of law, the law is supreme over the acts of the government and the people. The rule of law suggests a number of prepositions:

i. Adherence to the rule of law as a guide to everyday social and legal interaction and a means of prevention of anarchy;

ii. Rule of law as an indicator of all being equal in eyes of the law;

iii. Equality in the law as well as before the law;

iv. $\quad$ The citizen should be governed by the law and should obey it;

v. The law should be such that citizens and aliens will be able to be guided by it;

vi. Constitutionalism and the rule of law are cornerstones of the constitution and reflect a country's commitment to an orderly and civil society in which all are bound by enduring rules, principles and values of a constitution which is the supreme source of law and authority;

vii. Rule of law also entails the social contract between the state and individuals by pre-established and known laws. The states no less than the individuals it governs must be subject to and obey the law. The state's obligations to obey the law are central to the very existence of the rule of law. Without this obligation, there would be no enforceable limit of the state's power over individuals;

viii. The supremacy of the law over all citizens, no one, no politician, no government, no judge, no union, and no citizen is above the law. All are subject to the law. No one can pick or choose the law to observe and obey. Each must accept the rule of all laws. ${ }^{7}$

In the World Rule of Law Justice Reform Project conducted recently, the top three overall performers in the 2017-2018 WJP Rule of Law Index were Denmark (1), Norway (2), and Finland (3); the bottom three were Afghanistan (111), Cambodia (112), and Venezuela (113). ${ }^{8}$ The top three and bottom three performing countries have not changed since the 2016 Index. $^{9}$

In the same report, Countries leading their regions in overall rule of law scores included: Nepal (South Asia), Georgia (Eastern Europe and Central Asia); Ghana (Sub-Saharan Africa); Uruguay (Latin America and the

\footnotetext{
${ }^{1}$ Charlie Nwekeaku, The Rule of Law, Democracy and Good Governance in Nigeria. Global Journal of Political Science and Administration Vol.2, No.1, pp.26-35, March 2014, page 3

${ }^{2}$ Ibid.

${ }^{3}$ A. M. Yusuf. A Conceptual Analysis of the Rule of Law in Nigeria. https://www.researchgate.net/publication/321017220 Accessed 31 July, 2019

4 Professor Emmanuel Omoh Esiemokhai in a paper titled: The Rule of Law in Nigeria. Available at http://www.gamji.com/article8000/NEWS8046.htm Accessed 30 July 2019

${ }^{5}$ The Greek philosopher, Politics, Vol 111, page 16

${ }^{6}$ Ibid

${ }^{7}$ A. M. Yusuf. A Conceptual Analysis of the Rule of Law in Nigeria. https://www.researchgate.net/publication/321017220 Accessed 31 July, 2019

${ }^{8} \mathrm{https}$ //worldjusticeproject.org/our-work/research-and-data/wjp-rule-law-index-2017-2018. Accessed 1 August 2019

${ }^{9}$ Ibid.
} 
Caribbean); United Arab Emirates (Middle East and North Africa); New Zealand (East Asia and Pacific), and Denmark (Western Europe and North America, defined as EU + EFTA + North America). ${ }^{1}$

Can there be rule of law without an independent judicial arm of government? We are afraid, there cannot. The constitution of the Federal Republic of Nigeria by virtue of section 158 further strengthens the independence of the judiciary by stating in its subsection 1 that with respect to exercising its power to make appointments or to exercise disciplinary control over persons, the National Judicial Council, ${ }^{2}$ shall not be subject to the direction or control of any other authority or person. In furtherance of the above, item 21 of the Third Schedule, paragraph I (e) states that the National Judicial Council shall have power to collect, control and disburse all moneys, capital and recurrent, for the Judiciary. The judiciary administers itself subject to the principles of checks and balances considering the role of the executive arm of government and the legislature in the appointment and discipline of certain judicial officers. ${ }^{3}$ This role includes the recruitment and working of the magistrates and other staff working in the courts. The judiciary interprets and enforces rules for the orderly and efficient conduct of judicial administration as well as the society.

\section{Building and Sustaining Rule of Law for Good Governance in Nigeria}

Rule of law, transparency, and accountability are not merely technical concepts of administrative procedure or institutional design. They are outcomes of democratizing processes driven not only by committed leadership, but also by the participation of, and contention among, groups and interests in society processes that are most effective when sustained and restrained by legitimate, effective institutions. ${ }^{4}$

A better understanding of how institutional capacities within countries form a building block for effective responses to good governance systems and policies is essential for sustaining human development gains, including progress towards the Millennium Development Goals. ${ }^{5}$ It is high time we build and make our institutions work. We should not promote individual prowess and thriving sycophancy in lieu of working institutions. In public Universities, there have been proven cases of lecturers engaged to serve as role models and shape the future of the younger ones turning around to molest and frustrate our young minds. ${ }^{6}$ In the security apparatus of the nation, especially, in the Nigerian Police, one Abba Kyari, a fine officer of the Nigerian Police is usually sent with his team known as the Inspector General of Police Special Squad to investigate and arrest situations which seems to be out of control for the Nigerian Police authorities. Such gesture should be institutionalised and not individualised. It is not the way to go for Nigeria as a nation. The Late General Sanni Abacha administration in the 1990s notoriously looted upwards of $\$ 3$ billion. ${ }^{7}$ Till date, Abacha loots are still being recovered by the Federal Government of Nigeria. Since then, government institutions like the Economic and Financial Crimes Commission and Independent Corrupt Practices Commission have always vowed to reduce corruption to its barest minimum. If institutions had worked in Nigeria, would a single Head of State be able to stash the future fortune of the unborn generation far away outside the shores of the nation? We think not? But Late General Sanni Abacha does not work in the oil sector. It is in our view, connivance by those players in the Oil sector that would make an individual Head of State to stash away billions of dollars of our collective wealth into several foreign countries. ${ }^{8}$ Today we are all victims of very bad and infrastructural facilities collapsing before our very eyes in Nigeria. Does that mean the rich also cry?

Recently, the Nigerian nation was saturated with the news of budget padding. There is a need to ask some pertinent questions in the budgeting processes for our public expenditures. Who prepares the budget for the various Ministries, Departments and Agencies (MDAs)? Are they robots? Definitely, not robots, they are humans endowed

\footnotetext{
${ }^{1}$ Ibid

${ }^{2}$ The other bodies covered in the aforestated provisions of section 158 (1) are Code of Conduct Bureau, the Federal Civil Service Commission, the Federal Judicial Service Commission, the Revenue Mobilisation and Fiscal Commission, the Federal Character Commission, and the Independent National Electoral Commission.

${ }^{3}$ See section 6, 153 (1) (i), paragraph (d) of the 3rd schedule to the Constitution, Section 271(1), and Section 292 (1) (a) (ii) of the 1999 Constitution 292 (b) of the Constitution of the Federal Republic of Nigeria and cases such as Elelu-Habeeb vAttorney General of the Federation (2012) All FWLR; (2012) 2 MJSC (Pt. 1110), Suit No: SC.281/2010

${ }^{4}$ Michael Johnston, Op cit. 1

${ }^{5}$ MDGP Progress Report. Towards Sustaining Strong Institutions: Governance Principles, Institutional Capacity and Quality. Chapter 8, Page 270

${ }^{6}$ www.premiumtimesng.com Why I demanded Sex from female student - Dismissed OAU Professor. 6 July 2018 . Accessed 12 February 2020. www.pulse.ng OAU student accuses another lecturer of sexual harassment. 15 January 2020. Accessed 12 February 2020. www.saharareporters.com Sex for marks: BBC Releases Faces of Lecturers Sexually Harassing Students 7 October 2019. Accessed 12 February 2020. www.punchng.com Sexual harassment: UNILAG suspends another lecturer. 9 October 2019. Accessed 12 February 2020.

${ }^{7} \mathrm{https}: / / \mathrm{m}$.guardian.ng US to monitor usage of returned Abacha Loots in Nigeria - The Guardian Nigeria of 5 February 2020 . Accessed 12 February 2020. https://punchng.com FG disburses $\$ 103.64 \mathrm{~m}$ Abacha loot to the poor - Punch Newspaper of 22 October 2019, accessed 12 February 2020

${ }^{8}$ https://www.cfr.org Nigeria's Sani Abacha: Where is the Loot? Council on Foreign Relations, 26 November 2013, accessed 13 February 2020 www.theguardian.com Switzerland to return Sani Abacha 'loot' money to Nigeria. https://www.worldbank.org World Bank Monitoring of Repatriated Abacha Funds - World Bank Group 4 December 2017, accessed 13 February 2020. https://www.transparency.org Returning Nigerians'stolen millions - Transparency International 3 August 2018, accessed 13 February 2020.
} 
and clothed with the shining garment of public trust to manage our commonwealth. Why would an officer of government inflate budgetary provisions when the budget may be financed by way of external borrowings? There must surely be in existence, institutional checks and internal control for budget authorisation before it goes to the Parliament for appropriation and final passage into law through the assent of the Head of the executive arm of government. Budgeting procedures must be institutional - based and not on the sentiments of individuals saddled with the budget preparatory processes.

What about clearing of goods at the Nigerian Ports Authority? A car will be imported to Nigeria through our Waters and men of the Nigerian Customs Service will undervalue and under-assess the Customs Duty payable. The undervalued car or goods will be cleared through a weak institutional process and the same agency of government will be harassing citizens with such vehicles of goods within the country. A strong institution will go after the officers of the Nigerian Customs who were tardy in their assessment of the import and excise duties payable into the coffers of the nation from the Ports.

Countless developmental efforts have failed because countries lack institutions with the ability to sustain their economic policies. The crisis in Argentina-triggered in large part by the country's reliance on an inflexible currency regime and by its inability to rein in fiscal flagrancy by local governments is a case in point. Meanwhile, numerous discussions at Monterrey highlighted weak institutional capacity as a major obstacle to economic development. ${ }^{1}$

\section{Challenges of Building and Sustaining Strong Institutions in Nigeria}

The Concept of Federal Character is one of the challenges facing the enforcement of stronger institutional governance in Nigeria. Federal Character, though, good, entails having fair representation in the dividends of democracy such as use of quota system by various geo - political zones as well as a system of inclusion in government employment and appointment. Section 14 (3) of the constitution provides:

The composition of the Government of the Federation or any of its agencies and the conduct of its affairs shall be carried out in such a manner as to reflect the federal character of Nigeria and the need to promote national unity, and also to command national loyalty, thereby ensuring that there shall be no predominance of persons from a few State or from a few ethnic or other sectional groups in that Government or in any of its agencies.

Nepotism through ethnicity and religion has eroded this national value being promoted by the afore mentioned section. It is a notorious fact that government offices are populated based on who heads the office and the dictate of his wishes in the administration of the resources of the office. This, in turn promotes the rule by individuals in lieu of institutions. For some years now, the Federal Character Commission was not reconstituted until March 2020 when a list of its new appointees nominated for confirmation by the Senate was sent to the Senate. ${ }^{2}$ Appointments and employments were made by Ministries, Departments and Agencies of government in all these years. This practice encourage the reign of individuals over institutional checks and balances in the administration of government institutions. In the same vein, enthroning the principles of equal representation through Federal Character or Quota System slaughters merit - based appointments on the altar of equal representation.

The constitution intends to ensure democratic representation plays out in the art of governance through fair representation. This is a welcome development. Section 14 (4) of the constitution lends credence to this when it provides as follows:

(4) The composition of the Government of a State, a local government council, or any of the agencies of such Government or council, and the conduct of the affairs of the Government or council or such agencies shall be carried out in such manner as to recognise the diversity of the people within its area of authority and the need to promote a sense of belonging and loyalty among all the people of the Federation.

The keywords in the above subsection is diversity but where diversity as we have argued above is not based on merit, integrity and other core values, individualism will thrive to undermine institutionalism.

Another major challenge militating against institutional governance is corruption. Corruption enriches a few people with the resources of the majority. The efforts of the various law enforcement agencies set up to tackle the menace of governance has yielded some results over the years. It is commendable because it is an herculean to embark on the fight against corruption when you might as well be a product or beneficiary of a corrupt leadership system which has the bane of the Nigerian governance structure over the years. Corruption through individualistic tendencies for control ensures that the systemic checks and balances are relaxed for the dominant wishes of the individual head of organisations. It is pertinent to note that while the Nigeria reels of both domestic and international debt accumulation, banks and multinational companies declares profits year in and out. The

${ }^{1}$ Carol Graham, Report on Strengthening Institutional Capacity in Poor Countries: Shoring Up Institutions, Reducing Global Poverty. Available at https://brookings.edu accessed 2 August 2019

${ }^{2}$ Buhari Appoints members of Federal Character Commission reported on 29 April 2020 via www.cable.ng, https://www.premiumimesng.com, https://leadership.ng, https://thesourceng.com. All these news medium were last accessed on 2 May 2020 
determining factor between these two comparisons is the corporate governance structure. It is pertinent to ask, when was the audit report of any known government agency implemented to the letter. Yet, we have the office of the Auditor - General of the Federation. This is not to say that the office has renege in its constitutional mandate but were their efforts as recommended on a yearly basis implemented?

Flowing from the short discourse on corruption above, another major challenge identified in the enthronement of institutionalism for good governance over individualism in Nigeria that has encouraged unethical behaviour is the lack of accountability of the public and private sector mangers to the people to the people they ought to represent and serve. ${ }^{1}$

\section{Effect of Strong Institutions on Good Governance in Nigeria}

The effect on strong institutions on good governance cannot be over emphasised. Sustaining strong institutions automatically dovetails into good governance. Building strong institutions makes the system of service delivery work. It erases dependency on individual exploits and prowess. It negates praise - singing and sycophancy towards individuals. In the Civil Service, strong institutions will not leave a task and service delivery undone and unattended, until a staff returns from annual leave. No one will hide the official file of a client until bribery and corruption is fully perfected. Hiding an official file until gratification is paid to the officer assigned and paid to work on the file is official corruption. It is not the norm but the rusty storm in the Civil Service.

Strong institutions are effective tools in eradicating corruption. A system with predictable outcome cannot be corrupted to a large extent. This is because checks and balances as building blocks for systemic growth will ensure a thorough process in service delivery. Servicom was introduced by the Federal Government a few years ago to eradicate poor service delivery in the Civil Service. ${ }^{2}$ Are we not back to poor service delivery in our Civil Service? Is Servicom still functional? If everyone does the right thing and eradicate tools of blackmailing the uncompromising civil servant, good governance will be the better for it. The effect of sustaining rule of law is that the concept of the rule of man and individualism will be suppressed and the citizens will enjoy good governance and the government will enjoy patriotism and public trust.

In furtherance of the above, the various elected members of the States'Houses of Assembly should be independent and collaborate to a very large extent with the state Governors. It is a notorious fact in Nigeria that the various Houses of Assembly are in the firm grip of the Governors for each State. This development will kill the drive for checks and balances and the concept of Separation of Powers. The case of Elelu - Habeeb \& Anor vs. Attorney General of the Federation \& Others is highly instructive. ${ }^{3}$ In this case, former Governor Bukola Saraki of Kwara State went beyond his constitutional powers to remove the then Chief Judge of the state. This removal was confirmed by the Kwara State House of Assembly without by any of the actors in this constitutional recklessness to the National Judicial Council. The then Chief Judge in question protested to the National Judicial Council and filed an action at the Federal High Court in Ilorin seeking his reinstatement. The matter went on appeal to the Court of Appeal and the Supreme Court. In the final analysis, the Supreme Court held as follows:

...that in the resolution of the issue at hand, the entire provisions of the 1999 Constitution iii section 153 (1)

(i), (2), 27 1(1) (a) (ii) and paragraph 21 of part 1 of the Third Schedule to the Constitution of the Federal Republic of Nigeria 1999 dealing with the appointments, removal and exercise of disciplinary control over judicial officers, must be read, interpreted and applied together in resolving the issue of whether or not the Governor of a State and the House of Assembly of a state can remove a Chief Judge of a State in Nigeria without any input of the National Judicial Council. This is because the combined effect of these provisions of the Constitution has revealed very clear intention of the framers of the Constitution to give to the National judicial Council a vital role to play in the appointment and removal of judicial officers by the Governors and Houses of Assembly of the State... in the result. I entirely agree with the two courts below that having regard to these relevant provisions of the 1999 Constitution, the Governor of Kwara State and the House of Assembly cannot remove the Chief Judge of Kwara State from office without the participation of the National judicial Council in the exercise. ${ }^{4}$

The above typifies a typical case of rule of man in lieu of rule of law which negates good governance. Therefore, from these clear provisions of the Constitution which are far from being ambiguous, the Governors of the States and the Houses of Assembly of the States cannot exercise disciplinary control touching the removal of Chief Judges of States or other judicial officers in the States. ${ }^{5}$

It seems there is a dangerous dimension in wilful disobedience of court orders by government institutions in

\footnotetext{
${ }^{1}$ Dibie, R. Public Management and Sustainable Development in Nigeria: Military-Bureaucracy relationship. (Hampshire: Ashgate Publishing Ltd, 2003)

${ }^{2}$ https://nimasa.gov.ng Servicom Initiative was established on 21 March 2004 as Presidential Initiative pledging to rendering quick and satisfactory service delivery in all government Agencies to all Nigerians. Accessed 13 February 2020. https://servicom.gov.ng accessed 13 February 2020

3 (2012) 13 NWLR (Pt. 1318) 423

${ }^{4}$ Supra n. 52 p. 423.

5 "Per Mohammed, J.S.C.
} 
Nigeria. This is a recent and very saddening trend to good governance and rule of law. ${ }^{1}$ Wilful disobedience of court orders breeds impunity, anarchy and resort to self - help by citizens. Law and order is the tonic for a vibrant egalitarian society. A situation where a government chooses the favourable orders of court to obey will not sustain rule of law and good governance. ${ }^{2}$ Disobedience of court orders portends danger for Nigeria's nascent democracy. Anarchy will be a global disaster if Nigeria should be plunged into another civil war. The global humanitarian crisis will be unimaginable for a nation of over 180 million populations. ${ }^{3}$

\section{Recommendations}

This paper recommends as follows:

Service Compact otherwise known as Servicom should undergo further reforms especially on enforcement of tardy and time-wasting service delivery using the mechanism of the Civil Service across the various tiers of government. Sustaining independence of the judiciary should be a clearly defined objective by the Judiciary itself as an institution. Merit and integrity should be the hallmark in appointing judicial officers in line with the Revised Guidelines for Appointment of Judicial Officers as handed down by the National Judicial Council in November, 2014. The principles and spirit of these guidelines should not be circumvented to favour the 'who knows who' as it is being alleged.

Secondly, we must continually strengthen the electoral process by imbibing electronic voting and bringing electoral offenders to book through the instrumentality of the law no matter whose ox is gored. Nigeria should have come of age in electoral probity. It is not a proud assertion to advise Nigeria to emulate Ghana in terms of electoral reforms but the reality is that we have to emulate Ghana and other seemingly lesser African countries to strengthen our electoral reforms systems to move away from the person and the integrity of the head of the electoral agency alone. Can he work alone? It is practically and theoretically unarguable for the Independent National Electoral Commission (INEC) Chairman to work alone. This calls for an added voice that there is an urgent need to build and strengthen systemic operations of the electoral agency.

We must continue to focus on long term institution building to save the nation from perennial short and medium term developmental failures.

Exercise your right to hold your elected officials to account. Exercise your right to freedom of information and share your opinion with your elected representatives.

We must be the change by promoting stronger institutions through inclusion and respect towards people of different backgrounds, ethnic origins, religions, gender, sexual orientations or different opinions. Together, we can help to improve conditions for a life of dignity for all. We should be tired of individualising service delivery in our polity.

\section{Conclusion}

Rule of law must be sustained by the governed and the government. It is not one - sided and should never be. Any concept of legislation which is not for the mutual benefit of the nation is an exercise in futility. The law must not only rule, it must realise its objectives for the common realisation of our commonwealth. It is then that we can have good governance. This paper is a wake - up call on our institutions to rise up and do the needful in order for the citizenry to enjoy the dividends of democracy. Strong institutions weaken autocracy and autocratic tendencies and strengthen democracy for the good of all. Sustaining strong institutions promote merit and abhor mediocrity.

\footnotetext{
${ }^{1}$ www.saharareporters.com Buhari Has Disobeyed 40 Court Orders Says Amnesty International Lawyer. 25 November 2019. Accessed on 13 February 2020. www.punchng.com Buhari has disobeyed court orders 29 September 2019. Accessed 13 February 2020. www.premiumtimesng.com How Buhari aministration serially disobeys court orders 11 June 2017. Accessed 13 February 2020. www.tribuneonlineng.com Disrespect of Court Orders, rule of law under Buhari worse than Abacha 11 December 2019. Accessed 13 February 2020

${ }^{2}$ Ibid.

${ }^{3}$ https://www.quora.com The World Bank and the United States Census Bureau puts Nigeria's population as of 2013 at 173.6 million. Accessed 13 February 2020
} 